\title{
The Usage of Data Mining Technology in Financial Information System: An Application on Borsa Istanbul
}

\author{
Ceren Uzar ${ }^{\mathrm{a}}$ \\ ${ }^{\mathrm{a}}$ Dr. Ceren Uzar, Department of Accounting and Tax Applications, Fethiye A.S.M.K. Vocational School, Mugla Sitk1 Kocman \\ University, 48300, Fethiye-Mugla, Turkey.
}

\begin{abstract}
Data mining technology is one of the new technologies that have become increasingly popular. Data mining enables to form forecasts and models regarding future by making use of past data. It can be costly, risky and time consuming for enterprises to gain knowledge. Firms gain important competitive advantage by data mining methods. This study analyzes on the readiness to implement and the extent of utilization of data mining technologies in the Financial Information Systems (FIS) in Borsa Istanbul and also researches the level of understanding of, perceptions of and readiness to implement data mining technologies within the Borsa Istanbul. Analysis was undertaken using SPSS. Manufacturing and financial enterprises are the universal of this study. Primary data were obtained by using survey method and questionnaire technique and findings of the study were evaulated. Technological, organisational and human resources issues had a significant role in the decision to, or not to utilize data mining technology. The ability to use data mining technology was found to be increased the performance of the Financial Information System.
\end{abstract}

Keywords: Data Mining; Information Systems; Financial Information System

JEL classification: $\mathrm{M} 13$

\section{(C) 2014 Published by SSBFNET}

\section{Introduction}

The first concept associated with a large amount of data is "Data Mining". Data Mining (DM) is a process which discovers the patterns and relations within data by using many analysis tools and uses such patterns and relations for making valid estimations. The purpose of data mining is to create decision making models related with estimation of the future conducts based on the analysis of the past activities (Koyuncugil \&Özgülbaş, 2009).

DM can also be evaluated as the outcome of the natural development process of the information technologies. Very large scale data may be considered as a data mine which accommodates valuable data within their large scale databases in different fields. DM is defined as the process of producing meaningful information, which was unknown previously, based on such data (Albayrak\&Y1lmaz, 2009). Data mining is the process of revealing the previously

${ }^{\mathrm{a} C}$ Corresponding author. Ceren Uzar, Tel.: +90 2526110682 
undiscovered information basd on various data maintained in data storages and using them for realizing the action plan. At this point, it is not a solution alone but is a tool which supports the decision making process to reach to the solution and which provides information required for solving the specific problem (Akgöbek\&Çakır, 2009).

This study analyzes on the readiness to implement and the extent of utilization of data mining technologies in the Financial Information Systems (FIS) in Borsa Istanbul and also researches the level of understanding of, perceptions of and readiness to implement data mining technologies within the Borsa Istanbul.

\section{Literature Review}

Use of data mining in the field of finance has gradually become more common in the world. Information such as client data, portfolio data, company data etc. are stored in data bases. The data mining techniques are used for evaluation and pre-emption purposes in many fields such as credit risk, market risk, portfolio management etc. Together with the growing credit industry, use of credit scoring models for credit evaluation has increased (Huang et al., 2007). In credit scoring, a loan is classified as "good" or "bad". Use of data mining for estimation of credit risk is very common (Vellido et al., 1999). In this respect, Kotsiantis (2007) has implemented different data mining methods to the data set and estimated the credit risk.

Portfolio management is an important subject in terms of investments. The purpose of portfolio management is to create a portfolio based on risky active values and to obtain maximum revenue under current risk or to minimize the risk in return for the obtained income (Hung et al., 1996). With the help of data mining and optimization techniques, the investors allocate their capitals to proper commercial activities and enable their profits to be at a maximum level or enable their risks to be at minimum level (Dass, 2006). Also considering the classification problems in 2000s, newer algorithms were used for trying to estimate financial failure. Anandarajan et al,, (2001) stated that financial failure may be estimated using genetic algorithms based on neural networks.

Evaluation of the financial health and the likelihood of going into default in respect of a firm are significant for the investors, loan grantors and the government. The most frequent problem encountered by the researchers using financial rates for estimation of financial failure is about which financial rates should be used or how to choose the financial rates to be used. Barnes (1987) claims in his study that the financial rates are chosed based on their popularity. Shirata (1998), examined the financial failure risk of the Japan companies in his study. His study is comprised of two steps. First he determined the financial ratios which he considered as the most appropriate for estimating financial failure for Japan companies. And later he analyzed them using data mining technique. The correct classification success of the created model is calculated to be $86 \%$. In this concept, estimating the bankruptcy risks of the firms using early warning models proved to be useful for the firms. Determining the bankruptcy risk levels of the firms is performed based on data mining techniques.

Therefore the researchers, use the decision tree among the data mining techniques considering the transparency of the algorithm in their studies (Akkaya\&Uzar, 2011). Data mining is used in different sectors in respect of financial failure 
estimations. Creating a model qualified as early warning systems which estimate financial failure especially in terms of banks is significant in terms of efficiency of the financial system.

Karacabey (2006) tried to estimate the financial failures of 39 Turkish banks with private capital in his study. Torun (2007) developed estimation models on the 1992-2004 year data of industrial business operations whose stock shares are processed in Istanbul Stock Exchange, using traditional statistical techniques and artificial neural networks. As a result of this study, it is concluded that use of artificial nerve network, as one of the data mining techniques, will be beneficial for estimation of financial failure. Chen and $\mathrm{Du}$ (2009), tried to estimate the financial failure of 68 companies in Taiwan Stock Market using artificial nerve networks and data mining methods.

Manipulation is of a great concern on the capital markets. Aktaş et al. (2011) estimates in his studies whether financial information manipulation is performed by means of multi-dimensional statistical methods and artificial nerve networks. As a result of their analysis, they determined that the estimated multidimensional statistical models can be used as early warning systems which provide for financial information manipulation. It is determined that artificial nerve networks are insufficient on this subject.

Related with this subject, the system named as Stock Watch implemented by New York Stock Exchange should be mentioned. New York Stock Exchange uses a computerized early warning system for determining the manipulation and inside learner trading. Stock Watch is defined by NYSE (2011) as 'NYSE's state of the art computer supported monitoring unit which monitors possibly illegal abnormal price and amount activities for the securities registered in NYSE (www.nyse.com, 20.02.11).

Istanbul Stock Exchange determines the transactions via the mathematical system it established. For instance, it determines the investor making transaction on the same share via separate intermediary organizations. Via such system Istanbul Stock Exchange algorithmically determines investor conducts. However, Istanbul Stock Exchange has become a member of Intermarket Monitoring Group. Membership to Intermarket Monitoring Group founded in 1980 with the participation of stock markets and market organizers, enables Istanbul Stock Exchange to exchange information with other member organizations in market monitoring and supervision activities and to pursue its activities regarding manipulation determining more effectively.

Another example for the early warning systems is ATOMS (Automated Tools for Market Surveillance) used by Thailand Stock Market (SET 2006). The system named ATOMS is established in 1995 in order to warn the market in Thailand Stock Market. The Automatic Warning System included in ATOMS system, compares the price and/or amount activities with previous values in real time and gives a sound warning for extraordinary occasions (www.set.or.th, 20.02.2011). Although it is known that data mining is used in Stock Watch system there is no such information for ATOMS. However, since both systems are directed to determining the extraordinary price and amount changes, the essence of both systems is based on discovering hidden information and relations within large scale data. It can be mentioned that this pretty much overlaps with the definition of data mining. 
Koyuncugil (2007) defined in his study a risk model based on early warning data mining which will make the definition of the pioneer indicators, which can render ideas for risk determination, possible. Koyuncugil and Özgülbaş (2008) determined in their study the financial profiles of SMEs in transaction at Istanbul Stock Exchange and the financially strong and weak aspects of the SMEs based on these profiles.

\section{Research and Methodology}

The purpose of this study is to determine the level of using data mining in financial information processes of the business operations acting in manufacturing industry and financial organization sectors of Istanbul Stock Exchange. Within this scope, the study carries a definitive and discovering quality. There are 120 manufacturing business operations and 109 financial organizations acting in Istanbul Stock Exchange. In our study we obtained 142 questionaires. Said questionnaires were answered by the accounting/financial managers of said organizations.

The business operations as the subject of the study are comprised of Istanbul Stock Exchange manufacturing industry and financial organizations. These companies were selected since they are open to public and they relatively completed their institutionalization levels. The manufacturing industry and financial organizations in Istanbul Stock Exchange where it is of great concern to monitor particularly the financial details in time and correctly in terms of scale and the related interest groups create the universe of the study. Within this scope, survey method and questionnaire techniques were used for obtaining the primary data required. Rahman (2008) was used for preparing questionnaire form. First the reliability of the questionnaire form which is used was analyzed. The result of reliability is given in Table 1.

Table 1. Reliability Analysis

\begin{tabular}{|l|l|}
\hline Cronbach's Alpha & N of Items \\
\hline, 854 & 57 \\
\hline
\end{tabular}

Cronbach Alpha .854, referring to the reliability measurement value is found. Such value mentions that the scale is highly reliable.

In the study, first the data characters of the financial information users will be analyzed. Within this scope, the satisfaction level from the current financial information system, the awareness of data mining applications, the role of data mining applications in organizational decisions and in case data mining is not used, the reasons for such non-use will be set forth. Later the following hypothesis will be tested:

H1: The arithmetic average of the variables for perception of the effect of data mining on organizational performance is higher than the level of 3.5 .

$\mathrm{H} 2$ : There is a relationship between knowledge of data mining and the intention of accepting the data mining technology. 
H3: Using data mining term in organization affects the information level.

H4: Using another term instead of data mining term in organization affects the information level.

The methods used in analysis are as follows;

H1: The arithmetic average of the variables for perception of the effect of data mining on organizational performance is higher than the level of 3.5. In order to study this hypothesis whether the average of eight variables for perception of the effect of data mining on organizational performance is higher than the level of 3.5 was analyzed using one sample test t.

H2: There is a relationship between knowledge of data mining and the intention of accepting the data mining technology. Two variables are used in the analysis in order to study this hypothesis. Correlation analysis is applied in order to test the hypothesis.

H3: Using data mining term in organization affects the information level. Chi-square test was used in order to test the hypothesis.

H4: Using another term instead of data mining term in organization affects the information level.Chi-square test was used in order to test the hypothesis.

\section{Empirical Data And Analysis}

In this section, satisfaction from the current system and use of Data Mining in FIS will be discussed. Furthermore the hypothesis will be tested.

\subsection{Satisfaction from the Current System}

Level of satisfaction is handled using the financial information system available in Table 2. As seen on the table, while fifty three percent of the participants of the questionnaire are very satisfied from the current financial information system, twenty two percent of them stated that a regulation is required for regulation of the current financial systems. Only 4 people are not satisfied with the current financial information system.

Table 2. Satisfaction Level With The Current Financial Information System

\begin{tabular}{|l|l|l|}
\hline Satisfaction Level & $\mathrm{N}=142$ & $\%$ \\
\hline Very Satisfied & 30 & 21,1 \\
\hline Reasonably Satisfied & 76 & 53,5 \\
\hline Needs Regulation, but still usable & 32 & 22,5 \\
\hline Dissatisfied & 4 & 2,8 \\
\hline
\end{tabular}

As seen in Table 3, the median values of the significance of the quality factors for financial information system is between 4,21 and 4,27. This indicates that the subject four factors are significant for the financial information system. When the performance values of the financial information system are considered, the median values are between 4,04 
and 4,13. Briefly, the results indicates that four criteria are important in respect of the performance of the financial information systems, which are accurate, updated, complete and consistent performances.

Table 3. Signifiance and Performance Analysis

Paired t-test

\begin{tabular}{|l|l|l|l|l|l|}
\hline Quality Factors Of FIS & $\begin{array}{l}\text { Signifiance } \\
\text { (Mean) }\end{array}$ & $\begin{array}{l}\text { Performance } \\
\text { (Mean) }\end{array}$ & Mean of Differences & $\mathrm{t}$ & $\mathrm{p}$ \\
\hline Accurate & 4,23 & 4,08 & 0,155 & 2,186 & 0,03 \\
\hline Updated & 4,26 & 4,13 & 0,127 & 1,937 & 0,055 \\
\hline Complete & 4,20 & 4,04 & 0,162 & 2,677 & 0,008 \\
\hline Consistent & 4,27 & 4,08 & 0,183 & 3,208 & 0,002 \\
& & & & \\
\hline
\end{tabular}

There is a difference of 0,155 points between the significance level and current performance of the variable "the recorded data is complies with the real value". This difference is meaningful since $t=2,186, p=0,03<0,05$. The arithmetic average for the significance level of the subject variable is 4,23 and the arithmetic average for the performance level of the subject variable is 4,08 . There is a difference of 0,127 points between the significance level and current performance of the variable "the data recorded in your system are update". This difference is not meaningful since $t=1,937, p=0,055<0,05$. The arithmetic average for the significance level of the subject variable is 4,26 and the arithmetic average for the performance level of the subject variable is 4,13 . There is a difference of 0,162 points between the significance level and current performance of the variable "exact data are recorded for all proper values". This difference is meaningful since $t=2,677, p=0,008<0,05$. The arithmetic average for the significance level of the subject variable is 4,20 and the arithmetic average for the performance level of the subject variable is 4,04 . There is a difference of 0,183 points between the significance level and current performance of the variable "The indication of data value is identical for all cases". This difference is meaningful since $t=3,208, p=0,002<0,05$. The arithmetic average for the significance level of the subject variable is 4,27 and the arithmetic average for the performance level of the subject variable is 4,08 . The current performance for all variables does not satisfy the expected significance.

\subsection{Use of Data Mining in FIS}

As seen on Table 4, while $53,5 \%$ of the participants use analytic program for analyzing the financial data, $46.5 \%$ stated that they do not use any analytic programs. The programs used by the participants replying yes are as follows:Rasyonet, Netsis, JD Edwards, Clementine, SAP BI, Oracle Apps 11, Intira, Microsoft Business SolutionsNavision, Oracle 9i, Saphyperion, Izobiz, Logo, Hyperion, Edw, Sap, Hfm, Excel,Link, Wolwokserp, Orarid, Kobnos, Forex, Axapta, One,Nebim v3, CPM.However, 29,6\% of the participants stated that they use data mining tool in their organizations. Said tools are as follows: Clementine, AS 400, JD Edwards, Oracle 9i. While 59,2\% of the participants indicated that they did not use data mining tool in their organization, 11,3\% indicated that they did not know. 
Table 4. Usage of Analytic/Data Mining Programme

\begin{tabular}{|l|l|l|l|}
\hline & Categories & Frequency & $\%$ \\
\hline \multirow{2}{*}{ Usage of Analytic Program } & Yes, please specify & 76 & 53,5 \\
\cline { 2 - 4 } & No & 66 & 46,5 \\
\hline Usage of Data Mining Technology & Yes & 42 & 84 \\
\cline { 2 - 4 } & No & 16 & 59,2 \\
\cline { 2 - 4 } & Don'tknow & 11,3 \\
\hline
\end{tabular}

H1: The arithmetic average of the variables for perception of the effect of data mining on organizational performance is higher than the level of 3.5 .

Table 5. The Effect Of Data Mining On Organizational Performance

\begin{tabular}{|l|l|l|l|l|l|l|l|l|}
\hline Statements & N & Mode & Median & Mean & Standart Deviation & T & DF & P \\
\hline 14.1 & 142 & 4 & 4 & 3,79 & 0,937 & 3,674 & 141 & 0,000 \\
\hline 14.2 & 142 & 4 & 4 & 4,08 & 0,71 & 9,817 & 141 & 0,000 \\
\hline 14.3 & 142 & 4 & 4 & 3,98 & 0,812 & 7,029 & 141 & 0,000 \\
\hline 14.4 & 142 & 4 & 4 & 4,07 & 0,759 & 8,952 & 141 & 0,000 \\
\hline 14.5 & 142 & 4 & 4 & 4,01 & 0,776 & 7,782 & 141 & 0,000 \\
\hline 14.6 & 142 & 4 & 4 & 4,06 & 0,806 & 8,227 & 141 & 0,000 \\
\hline 14.7 & 142 & 4 & 4 & 4,11 & 0,778 & 9,272 & 141 & 0,000 \\
\hline 14.8 & 142 & 4 & 4 & 4,12 & 0,803 & 9,194 & 141 & 0,000 \\
\hline
\end{tabular}

Whether the average of eight variables for perception of the effect of data mining on organizational performance is higher than the level of 3.5 was analyzed using one sample test $t$. The hypothesis is accepted since $p=0,000<0,05$ corresponding to $t$ statistics of all variables based on the table. The average rates of all variables are considered as bigger than the level of 3,5. While the highest average is the variable "it contributes to decision making speed" with 4,12 , the lowest average is the variable "it increases the quality of information obtained from FIS" with 3,79 although this is a high average.

Table 6. Perceived Impact Of Data Mining

\begin{tabular}{|l|l|l|l|l|l|}
\hline Statements & \multicolumn{2}{|l|}{ Agreement (ByNumber of Response) } \\
\hline & $\begin{array}{l}\text { Strongly } \\
\text { Disagree }\end{array}$ & Disagree & Neutral & $\begin{array}{l}\text { Agree } \\
\text { Strongly } \\
\text { Agree }\end{array}$ \\
\hline Impact on FIS & & & & \\
\hline 14.1. Lower down transaction & 3 & 9 & 35 & 63 & 32 \\
\hline 14.2. Increase thequality of information derived from FIS. & 0 & 2 & 24 & 75 & 41 \\
\hline 14.3. Increase overall FIS performance & 0 & 7 & 27 & 69 & 39 \\
\hline 14.4. Improve the quality of transaction & 1 & 4 & 18 & 80 & 39 \\
\hline 14.5. Reduce cycle time of organisation & 0 & 6 & 24 & 75 & 37 \\
\hline Impact On Decision Making & & & & \\
\hline 14.6. Fulfil information needs for th edecision making & 2 & 2 & 24 & 72 & 42 \\
\hline $\begin{array}{l}\text { 14.7. Provides decision support in supporting decision } \\
\text { making process }\end{array}$ & 2 & 1 & 21 & 74 & 44 \\
\hline 14.8. Contributes to the speed of decisionmaking & 2 & 1 & 23 & 68 & 48 \\
\hline
\end{tabular}


Considering the effects of FIS in data mining (Table 6), 66,9\% of the participants (95), indicated that they participated in the statement of low transaction cost. $81,7 \%$ of the participants (116) stated that they agree that the quality of the information obtained from FBS increased. $76,1 \%$ of the participants (108) stated that they agree that in increased all the FBS performance. $83,8 \%$ of the participants (119), think that the transaction improved its quality. Besides, $78,9 \%$ (112) of the participants stated that it decreases the return time of the organization. Many of the answers indicate that data mining has a positive effect on the financial information systems.

The rendered answers demonstrate that the effect of data mining on FBS is useful. Such technologies will ve beneficial in financial systems.

The definitive statistics (Table 6) indicate that the mean values for all the expression are bigger than 3 and furthermore mode and median values equal to 4 . In terms of participants, the effect of data mining on FBS is positive and meaningful.

When the effect of data mining on decision making is considered, $80,3 \%$ (114) participants stated that they agree with the expression "comprehensive information is required for decision making". 118 people agreed with the expression "it renders decision support in decision making process" and 116 people agreed with the expression "it contributes to my decision making speed". The definitive statistics (Table 6) indicate that the average values for all the expressions are bigger than 3 and the mode and median values equal to 4 . For the participants, the effect of data mining on decision making is positive and meaningful.

H2: There is a relationship between knowledge of data mining and the intention of accepting the data mining technology.

Two variables were used for studying this hypothesis in the analysis. Correlation analysis is applied for testing the hypothesis. As summarized in Table 7, there is a positive linear relation between knowledge of data mining and the tendency to accept the data mining technologies.

Table 7. Strength of Correlation: Knowledge of Data Mining and Intention of Acceptance

\begin{tabular}{|l|l|l|}
\hline Measurement of Strength & Value & Sig. \\
\hline Spearman sequence correlation &, 083 &, 324 \\
\hline
\end{tabular}

Kendall's tau-b and Spearman sequence correlation indicates meaningfull results (Spearman sequence correlation $=.083, \mathrm{p}=.324$ ). Considering this, there is a weak and positive correlation between knowledge of data mining and the intention of acceptance. There is not a meaningful relation between the knowledge of data mining and the intention of accepting data mining technology.

H3: Using data mining term in organization affects the information level. 
Table 8. Chi-square test

\begin{tabular}{|l|l|l|l|}
\hline & Value & df & Asymp. Sig. (2-sided) \\
\hline Pearson Chi-Square & 25,522 & 4 &, 000 \\
\hline
\end{tabular}

Chi-square test is applied for testing the hypothesis. The analysis results indicatePearson Chi-Square value as $25,522 \mathrm{r}$. $\chi^{2}$ table value is found as 9,488 in respect of degree of freedom $(\mathrm{df})=4$ and meaning level $(\alpha=0,05)$. Since $25,522>9,488$, the hypothesis is rejected. The same result is obtained from the sig. value of the above table. SinceAsymp. Sig. ( 2 -sided) value is $(p=, 000<0,05)$ the hypothesis is rejected. In other words using data mining term in organization does not affect information level.

H4: Using another term instead of data mining term in organization affects the information level.

Table 9. Chi-square test

\begin{tabular}{|l|l|l|l|}
\hline & Value & df & Asymp. Sig. (2-sided) \\
\hline Pearson Chi-Square & 13,082 & 4 &, 011 \\
\hline
\end{tabular}

Chi-square test is applied for testing the hypothesis. The analysis results indicate Pearson Chi-Square value as 13,082. $\chi^{2}$ table value is found as 9,488 in respect of degree of freedom $(\mathrm{df})=4$ and meaning level $(\alpha=0,05)$. Since $13,082>9,488$, the hypothesis is rejected. The same result is obtained from the sig. value of the above table. Since Asymp. Sig. (2-sided) value is $(\mathrm{p}=, 011<0,05)$ the hypothesis is rejected. In other words using another term instead of data mining term in organization does not affect information level.

\section{Conclusions and Implications}

There are 120 manufacturing business operations and 109 financial organizations acting in Istanbul Stock Exchange. In our study we obtained 142 questionnaires. Said questionnaires were answered by the accounting/financial managers of said organizations. The findings obtained in this study which aims to determine the levels of using data mining in financial information processes of the business operation active in Istanbul Stock Exchange manufacturing industry and financial organization sectors can be summarized as follows.

As a result of the examination, it is found out that the awareness level of the data mining technology is low despite being prepared for such technology. The results indicate that data mining technology may have a positive effect on FIS performance. It is concluded that the ability to use data mining is an important criteria for a good FIS. And also it is found that there is not a meaningful relation between the knowledge of data mining and the intention of accepting data mining technology.

In the study, initially the data characters of the financial information users were analyzed. In this scope, the level of satisfaction from current financial information system, the role of data mining applications on organizational decisions and in case data mining is not used, the reasons for such non-use is set forth. The results indicate that data mining term in organization does not affect information level and also using another term instead of data mining term in organization does not affect information level. 
The suggestions brought forward for improving the efficiency of financial information system may be listed as follows;

New technologies should be used for an effective FIS.

Using DM technologies in financial field will render a competitive superiority for the business operations.

The business operations which integrate DM techniques with their FIS, which enables estimation of future based on pevious data, enables the interest groups to make pre-emptive estimations and to determine the possible risks.

Considering DM as a significant tool of FIS highly contributes to the decision making process of the business operations.

Moreover, it imporoves the quality of information obtained from FIS, increases FIS performance, improves the quality of transaction and contributes to decision making speed.

Using data mining in FIS by the persons specialized in this field is suggested in terms of use of sources more fruitfully and of accesing to scientific, comparable and transparent information.

By means of effective data management, we can render better services and increase the satisfaction of interior and exterior clients.

For the future objectives of the organization to be consistent and accessible, such organization should be able to accurately inquire and report its history from different angles. In this meaning, data mining is a useful tool.

The FIS effectiveness of the business operations benefiting from DM technologies increases. DM technologies is a tool which provides benefit for the business operations in order to obtain a sustainable competition advantage.

\section{References}

Akgöbek, Ö., Çakır, F. (2009). Veri Madenciliğinde Bir Uzman Sistem Tasarımı, Akademik Bilişsim'09 - XI. Akademik Biliş̧im Konferansı Bildirileri 11-13 Şubat 2009 Harran Üniversitesi, Şanlıurfa.

Akkaya, G. C., Uzar, C. (2011). Data Mining And Application Of It To Capital Markets. International Journal Of Economics and Finance Studies, ISSN: 1309-80552011 (Online): 3 (2): 57-67.

Aktaş, R.,Kargın, M. (2011). Timeliness of Reporting and the Quality of Financial Information. International Research Journal of Finance and Economics. ISSN 1450-2887, 63: 71-77.

Albayrak, A. S., Yılmaz Koltan, Ş. (2009). Veri Madenciliği: Karar Ağacı Algoritmaları ve IMKB Verileri Üzerine Bir Uygulama. Süleyman Demirel Üniversitesi İktisadi ve İdari Bilimler Fakültesi Dergisi, 14 (1): 31-52.

Anandarajan, M., Lee, P. \& Anandarajan, A. (2001). Bankruptcy Prediction Of Financially Stressed Firms: An Examination Of The Predictive Accuracy Of Artificially Neural Networks. International Journal of Intelligent Systems in Accounting, Finance and Management, 10: 69-81. 
Barnes P. (1987), The analysis and use of financial ratios: A review article. Journal of Business Finance and Accounting, Vol. 14, nr. 4, Winter 1987, p. 449-461.

Chen, W.S., Du, Y. (2009). Using Neural Networks And Data Mining Techniques For The Financial Distress Prediction Model. Expert Systems with Applications, 4075-4086.

Dass, R. (2006). Data Mining in Banking and Finance:A note for Bankers. Indian Institue of Managemenet Ahmedabad, s.1-15.

Huang, C. L., Chen, M. C. \& Wang, C. J. (2007). Credit Scoring With A Data Mining Approach Based On Support Vector Machines. Expert Systems With Applications. 33: 847-856.

Hung, S. Y., Liang, T. B. \& Victor Wei, C. L. (1996). Integrating Arbitrage Theory and Artificial Neural Networks to support Portfolio Managament. Decision Support Systems 18: 301- 316.

Karacabey, A. A. (2006). Banka Başarısızlıklarının Düzeltilmiş Minumum Sapma Modeli ile Tahmin Edilmesi. Ankara Üniversitesi SBF Dergisi, 89-109.

Koyuncugil, A. S. (2007). Veri Madenciliği ve Sermaye Piyasalarına Uygulanması, Sermaye Piyasası Kurulu Araştırma Raporu. ss.1-17.

Koyuncugil, A. S., Özgülbaş, N. (2008) . IMKB'de İşlem Gören Kobi'lerin Güçlü ve Zayıf Yönleri: Chard Karar Ağacı Uygulaması. Dokuz Eylül Üniversitesi İktisadi ve İdari Bilimler Fakültesi Dergisi Cilt:23 Sayı:1, ss:1-21. Koyuncugil, A. S.,Özgülbaş, N. (2009). Data Mining: Using And Applications In Medicine And Healthcare. Journal of Information Technology, 2(2): 21-32.

Newyork Stock Ehxchange. 2011. Stock Watch, http://www.nyse.com/glossary/glossarylinks.html?a=1048903219379, (20.02.2011).

Rahman, M. S. A. (2008). Utilisation of Data Mining Technology within the Accounting Information System in the Public Sector: A Country Study-Malaysia. (Unpublished Doctoral Dissertation). Malaysia: University of Tasmania. Shirata, C. Y. (1998). Financial Ratios as Predictors of Bankruptcy in Japan: An Empirical Research. Proceedings of The Second Asian Pacific Interdisciplinary Research in Accounting Conference, http://www3.bus.osakacu.ac.jp/apira98/archives/pdfs/31.pdf, 20.11.12.

The Stock Exchange of Thailand. 2011. Investor Protection, http://www.set.or.th/en/regulations/protection/protection_p1.html, (20.02.2011).

Torun, İ. H. (2007). Finansal Başarısızlık Tahmininde Geleneksel İstatistiki Yöntemlerle Yapay Sinir Ağlarının Karşılaştırılması Ve Sanayi İşletmeleri Üzerinde Uygulama. Erciyes Üniversitesi. Sosyal Bilimler Enstitüsü. İşletme Ana Bilim Dalı. Doktora Tezi. 